\title{
THE BOOK OF THE MONTH
}

\section{A GREAT BOOK ON THREE GREAT RELIGIONS}

\author{
GEORGE A. BARTON, PH.D., LL.D. \\ Bryn Mawr College, Bryn Mawr, Pennsylvania
}

There are no religions that awaken in the English-speaking reader a keener interest than the three treated in this volumeJudaism, Christianity, and Mohammedanism. ${ }^{x}$ This is, of course, in part due to the fact that one of these religions is that which we profess, and another of them is the religion from which ours sprung. The interest is, nevertheless, justified on other grounds. These three religions are monotheistic, they have on the whole made monotheism potent ethically, and they command the assent of about half of the population of the globe.

The three religions are connected genetically, Christianity and Mohammedanism having sprung more or less directly from Judaism. That was Professor Moore's reason for treating them together in this second volume of his History of Religions in the International Theological Library. Each of the religions is remarkable: Judaism for its unique pioneer work in ethical monotheism; Christianity for its social conception of God, its high and unselfish ethical standards, and its universal ideals; Mohammedanism for its conception of the aloneness of God, its insistence on the absoluteness of the divine will, its conception of its own finality and universal mission, and its multiform development.

The author of the book is a remarkable scholar. Professor Moore is easily without peer among American students of religion, excelling all others in the breadth and accuracy of his knowledge. Then, too, of all the religions of the world Judaism and Mohammedanism have been the subjects of Professor Moore's especial study. His power of compressing into small compass the results of vast learning and extended studies is also very great. Both the subject and the writer accordingly combine to lead the reader to expect a great book, and he is not disappointed.

In 106 pages Judaism is sketched from its beginnings in the religion of ancient Israel to its forms at the present time. No part of its cult or life is neglected, and the history of medieval Judaism and the thought of Jewish philosophers are treated with a fulness and precision that make that part of the book noteworthy. Christianity is then treated in 279 pages, and it would be hard to find in such a small compass another such full history of Christian thought. The speculations of Fathers like Origen are followed through their various works; medieval movements and thought are fully studied; Roman Catholic as well as Reformation principles and practice are adequately and impartially set forth; all the editions of the works of an author like John Calvin have been consulted and the progress of his thought traced. Moreover, the author in formulating the forces that produced any given movement relies not only on the written documents that antedate it, but also upon the indefinable atmosphere of the age which

'History of Religions, II. By George Foote Moore, D.D., LL.D., Litt.D. Judaism, Christianity, Mohammedanism. New York: Charles Scribner's Sons, r919. Pp. xvi+552. \$3.00. 
preceded it-an atmosphere that escapes any except the master of wide knowledge and keen imagination.

Mohammedanism is then treated in 136 pages, in which an authoritative and illuminating sketch of Mohammedan thought from that of its founder to that of the Bahai sect is given. So thorough has Professor Moore's study of the modern movements of Babism and Bahaism been that, as one reads his pages, he almost gains the impression that the author was an eye-witness of the scenes which he describes.

In all three parts of the book the influence of the great Greek thinkers, Plato and Aristotle, is traced in a masterly manner on Jewish philosophers, Christian theologians, and Mohammedan theologians and philosophers. The book concludes with a selected bibliography and a good index. Great as the volume certainly is, it is a book for scholars rather than for students. To give in such brief space an adequate history of the thought of these three religions, it was necessary to presuppose a background of historical knowledge that the ordinary student does not possess. A good example of this is afforded by the reference to the unexplained Jansenists on page 356 . To the professional student, however, the book is of the highest value.

The author's attitude toward the beginnings of Judaism and Christianity constitute, in the judgment of the reviewer, a serious defect in the volume. Moses is given but the briefest mention and then only as a traditional figure (pp. 4, 5), whose influence on the religion of Israel was apparently quite negligible. Jesus is treated at the beginning of a chapter on the Apostolic age in a manner altogether too cursory. One gets the impression that he was, in the mind of the author, a sort of accidental starting-point for the whole movement. Mohammed is in comparison accorded a much more full and satisfactory treatment. The meagerness of the treatment of Jesus in comparison with the fulness of the consideration given to the abundant details of Nicene, medieval, and later theological development leaves an unpleasant impression. Doubtless the reason why Moses and Jesus are so briefly treated is that in the present state of criticism there are so many unsolved problems in connection with their history. Our author likes to tread on solid historical ground. Where the evidence is not clear, or receives at the hands of different scholars equally plausible interpretations, he prefers not to venture. Many readers will, however, regret his reserve.

Great as the author's insight has been and remarkable as his accuracy is, even the good Homer sometimes nods. Evidently Christian liturgics do not interest him as much as Christian thought. At all events in his treatment of the subject there are a number of inaccuracies of statement. ${ }^{x}$ Thus (p. 21 7 , first paragraph), not all the liturgies used in Spain, Gaul, Britain, and Ireland can be said to belong to the Gallcan class. All that can be said is that there were Roman and non-Roman liturgies. Again (p. 21 7 , par. 2, 1. 4), the "recitation of Psalms" is an error. The recitation of Psalms never, so far as we know, formed part of the "Proanaphora" to which the catechumens were admitted. It was a usage developed in the monastic service. If the last sentence of the same paragraph is intended to mean that the "Mass" came to be the only public service in the Western church, it is clearly a mistake.

On page $2 \mathrm{I} 8$, line 25 , one would like to know the authority for supposing that the candidates for baptism had received the creeds on the preceding Sunday. The

x The writer's attention was first called to these inaccuracies by Professor Royden K. Yerkes of the Episcopal Divinity School, Philadelphia. 
exact time is confessedly uncertain; it was probably on Thursday; it appears not to have been on Sunday. On page 219, lines $2 \mathrm{ff}$., it is said that "in the West the imposition of hands remained an exclusive function of the bishop." There are, however, traces of presbyterial confirmation in the West as late as the time of Innocent I (about 860 A.D.).

One would also like to know the authority for the statement on page 226 that "originally prayer was made for the martyrs." Presumably the author has some authority for it, but when was prayer made for the martyrs?

A striking feature of the volume is the complete detachment of the author from his subject. As already intimated, the treatment throughout is remarkably complete and able. In brief compass the intricate historical setting of the multifarious aspects of the three religions and the inner significance of the many varieties of their thought are clearly set forth. With almost uncanny cleverness the genetic origin and theological or philosophical significance of each sect of each religion are described. In all this the author never reveals his own attitude except in an occasional ironical utterance. Religion is such an intimate, personal thing that a reader naturally wishes to know what aspects of it appeal to so great a scholar after he has surveyed with such intimate knowledge all the religions of the world. One searches the book in vain for any self-revelation of the author, unless he finds it in his sarcasms. Thus on page 6I we find: "The vacillations and ambiguities in Philo's treatment of this subject should not be attributed to his inability to think clearly, but, as so often in theology, to the necessity of thinking ambiguously." Again on page 176 : "The antipathy of the common man for Origenism is easy to understand. Deprived of an imaginable God and an imaginable Heaven, what would be left of his religion?" Again on page 198 , in the footnote concerning the Latin translation of Rom. 5:12: "If the translator had rendered eo quod [instead of in quo] it is possible that the Western church might have been as little afflicted with original sin as the Greeks or the Orientals." Again, page 336, after referring to Calvin's view that the Nicene Creed was a hymn, suited to be sung, rather than a confession of faith, it is remarked in a footnote: "This way of disposing of the creed has been rediscovered by some modern Anglicans."

Doubtless self-repression is a virtue in a scholar, especially in a scholar who would write a scientific work on the great religions of the world. Doubtless also there is much in the history of any religion, so inconsistent and peculiar a being is man, to excite the innocent merriment of a sympathetic beholder. One wonders, nevertheless, if a book might not be as scientific, even if its author sometimes betrayed his enthusiasms. To confine one's self-expression to sarcasm is to run the risk that one will make religion seem a subject for irony rather than something to command the admiration and loyalty of every reader.

These defects should not, however, prevent us from rendering to the author hearty thanks for his remarkable work. A great theme treated in a masterly way by a great scholar has produced a really great book. It will be a long time before America will again see an equally able treatment of these three most important religions by one man in the compass of one volume! 